Transfusion Medicine
and Hemotherapy

\title{
Preservation of Human Cornea
}

\author{
W. John Armitage \\ School of Clinical Sciences, University of Bristol, UK
}

\author{
Keywords \\ Biopreservation - Storage - Cornea . \\ Transplantation - Eye banking · Hypothermia . \\ Organ culture
}

\section{Summary}

The successful outcome of the majority of corneal transplants depends on the presence of a viable corneal endothelium. This monolayer of cells lines the inner surface of the cornea and its primary function is to maintain corneal transparency by controlling the hydration of the collagenous stromal layer. Since human corneal endothelial cells do not readily proliferate, preservation of the endothelium is a primary aim of methods of corneal storage. Although some cryopreserved corneas have been transplanted successfully, the complexity of the cryopreservation technique and its potential for causing endothelial damage have limited its application. Hypothermia $\left(2-8{ }^{\circ} \mathrm{C}\right)$ is the most commonly applied method of storage, which allows storage for 7-14 days. Organ culture $\left(28-37^{\circ} \mathrm{C}\right)$, which extends storage time to 4 weeks, is used widely in European eye banks. Graft outcomes for corneas stored by these two techniques appear similar.

\section{Corneal Transplantation and Eye Banking}

The cornea is a deceptively simple, avascular tissue that is just over $0.5 \mathrm{~mm}$ thick and $11-12 \mathrm{~mm}$ in diameter. It is the major refractive component of the eye and critical to its function as a

\author{
Schlüsselwörter \\ Biologische Konservierung · Lagerung · \\ Hornhaut - Transplantation - Augenbank · Hypothermie . \\ Organkultivierung
}

\section{Zusammenfassung}

Der Erfolg der Mehrzahl der durchgeführten CorneaTransplantationen hängt vom Vorhandensein des funktionsfähigen Cornea-Endothels ab. Dieser Zell-Monolayer begrenzt die innere Oberfläche der Cornea, und seine primäre Funktion ist es, deren Durchsichtigkeit durch die Kontrolle der Hydrierung der kollagenösen Stromaschicht aufrechtzuerhalten. Weil menschliche CorneaEndothelzellen nicht ohne Weiteres proliferieren, steht die Erhaltung dieses Endothels bei allen Methoden zur Lagerung von Augenhornhäuten im Vordergrund. Obwohl auch kryokonservierte Corneae schon erfolgreich für eine begrenzte Anzahl von Transplantationen genutzt worden sind, hat die Komplexität der Methoden und der mögliche Endothelschaden bisher eine breite Anwendung verhindert. Hypothermie $\left(2-8^{\circ} \mathrm{C}\right)$ ist die am weitesten verbreitete Lagerungsmethode, sie erlaubt Lagerungszeiträume von 7-14 Tagen. Mittels höherer Temperaturen $\left(28-37^{\circ} \mathrm{C}\right)$ und Kulturtechniken, wie sie auch für andere Organe bekannt sind, ist es möglich, diesen Zeitraum auf bis auf 4 Wochen auszudehnen. Dese Technik machen sich derzeit die meisten Augenhornhaut-Bänke in Europa zunutze. Die Transplantationsergebnisse mit beiden Techniken gleichen sich aber offensichtlich.

lens are its transparency and shape. The cornea transmits a high percentage of light in the visible spectrum with remarkably little scatter. This transparency is a consequence of both the highly ordered structure of the collagenous stroma, which forms $90 \%$ of the thickness of the cornea, and the active control of stromal

\section{KARGER}

Fax +497614520714

Information@Karger.de

www.karger.com (c) 2011 S. Karger GmbH, Freiburg

Accessible online at:

www.karger.com/tmh
Prof. Dr. W. John Armitage

CTS Bristol Eye Bank, University of Bristol Bristol Eye Hospital

Lower Maudlin Street, Bristol BS1 2LX, UK

Tel. +44 117-342 4585, Fax -904 6624

w.j.armitage@bristol.ac.uk 
hydration by the corneal endothelium, a monolayer of mainly hexagonal cells that completely covers the inner surface of the cornea [1-2]. The spherical shape of the cornea is also governed by the stromal structure. In addition, as part of the outer coat of the eye, the cornea has to be strong enough both to withstand the intraocular pressure and to protect the delicate inner structures of the eye from trauma. The cornea also acts as a barrier to the ingress of potentially pathogenic micro-organisms.

In humans, corneal endothelial cells do not readily proliferate in situ as they are arrested in the $\mathrm{G}_{1}$ phase of the cell cycle [3]: dead endothelial cells are therefore not replaced by mitotic division, and the integrity of the endothelial mosaic is maintained by the migration and spreading of neighbouring cells. As a consequence, there is a decline in endothelial cell density (ECD) with increasing age [4]. In normal eyes, there is a sufficient reserve of endothelial cells to maintain corneal transparency throughout life; however, disease or injury can accelerate the decline of ECD, causing stromal oedema and loss of transparency. Endothelial dysfunction, whether from a primary cause such as Fuchs' endothelial dystrophy or secondary to previous ocular surgery such as cataract extraction, is a major indication for corneal transplantation [5-6]. Keratoconus, a tissue matrix disorder that does not affect the endothelium but causes thinning of the stroma and corneal ectasia, is another frequent indication for transplantation. Corneal transplants are also required for a range of other dystrophies as well as for trauma, scarring, and infection such as herpes keratitis. The age distribution of corneal transplant recipients is bimodal, with endothelial dysfunction being more common in the elderly and keratoconus occurring predominantly in younger patients.

Early corneal transplants relied on tissue from live donors, a practice that stemmed from a fear of transplanting tissue from the deceased. The first successful full-thickness corneal transplant (i.e. including all layers of the cornea) was achieved in 1905 [7-8]. The donor was an 11-year-old boy who had just undergone a therapeutic enucleation owing to a fragment of iron in his eye following an injury. The enucleated eye was kept in warm saline and the transplant operation started with a minimum of delay. It was not until the 1930s that use of corneas from deceased donors and storage of whole eyes in glass pots (moist chambers) in ice for several days were pioneered [9]. These developments led to the establishment of the world's first eye bank in New York in the 1940s. Since then, advances in corneal preservation techniques and increasingly successful efforts at encouraging eye donation have resulted in approximately 40,000 corneal transplants per annum in the USA, 20,000 per annum in Europe, and many thousands each year in other countries such as India.

\section{Donor Selection and Tissue Quality}

General standards for the quality and safety of tissue allografts are continually under review, especially with the in- creasing oversight of regulatory agencies and statutory enforcement of minimum standards, such as the EU Tissues and Cells Directive [10]. While selection criteria for cornea donors are to a certain extent less restrictive than for vascularized tissues (e.g. most malignancies, except of haematological or intraocular origin, are not contraindications to corneal donation and transplantation), corneal transplants have transmitted a range of diseases [11-12]. Careful donor selection and application of methods of appropriate sensitivity and specificity for the testing of donors [13] are of paramount importance for minimizing the risk of transmitting disease from donors to corneal allograft recipients.

In addition to donor medical assessment, eye banks also undertake an assessment of corneal quality. Since the majority of corneal transplants require grafts with a viable endothelium, endothelial examination of donor corneas by light microscopy and estimation of ECD are considered by eye banks to be important quality indicators in determining the suitability of corneas for transplantation. Eye banks in the USA typically set upper age limits for donors of 60-65 years. This practice was established before routine examination of the corneal endothelium and estimation of ECD became widely applied and, since ECD falls with increasing age, donor age was therefore used as a surrogate for ECD. However, with increasing demand for corneas, a major prospective, randomized trial was set up in the USA to compare 5-year corneal graft survival of corneas from donors 65 years or younger with corneas from donors between 66 and 75 years [14]. The minimum acceptable ECD was set at 2,300 cells $/ \mathrm{mm}^{2}$. There was little difference in graft outcome between the two study groups.

European eye banks tend to set higher age limits than 75 years, and some have no maximum donor age since endothelial examination is now routine. According to the 2010 European Eye Bank Association Directory report [15], the minimum ECD varies between eye banks, with almost $70 \%$ having a minimum of 2,000 cells $/ \mathrm{mm}^{2}$ and the others having minima ranging from 2,100 to 2500 cells $/ \mathrm{mm}^{2}$. Given the emphasis placed on donor ECD, the reliability of ECD estimates is clearly an important consideration [16-17]. Modelling the change in ECD after corneal transplantation suggests that a cornea with an ECD of 2,200 cells $/ \mathrm{mm}^{2}$ should retain sufficient endothelial cells to maintain corneal transparency for at least 25 years [4]. However, many transplants fail well before this for reasons other than the underlying attrition of donor endothelial cells [6]. Despite the presumed immune privilege of the anterior chamber of the eye, allograft rejection is an important cause of corneal graft failure [5-6], and recipient factors such as indication for transplantation have a major influence on graft survival [18].

\section{Corneal Preservation and Storage}

There are three main approaches to the preservation and storage of corneas containing living cells; viz. organ culture, hypo- 
thermia, and cryopreservation. Only the last of these currently offers the prospect of an unlimited storage time. Techniques for corneal cryopreservation were developed in the 1960s and applied clinically [19-21]. More recently, retention of endothelial function was reported after ice-free cryopreservation by vitrification of rabbit cornea in a high concentration of propane-1,2-diol [22]. But the complexity of cryopreservation and the potential for damage to the endothelium means that it is little used in routine eye banking, except occasionally for clinically urgent transplants where the principal aim is to save the eye [23].

Hypothermic storage at $2-8{ }^{\circ} \mathrm{C}$ is perhaps the most widely applied method world-wide; for example, all eye banks in North America use hypothermic storage owing to its perceived simplicity and its effectiveness. On the other hand, the majority of European eye banks use organ culture at $28-37{ }^{\circ} \mathrm{C}$ for storing corneas because of the extended storage time compared with hypothermic storage. Non-viable corneal tissue can be stored by freezing, by freeze drying, in glycerol, or in ethanol. This review will, however, focus on the preservation and storage of viable corneas by hypothermia and organ culture.

\section{Hypothermia}

The principle underpinning hypothermic storage of cells, tissues and organs is that cold reduces cellular demand for metabolic energy according to the Arrhenius relation. There are, however, deleterious effects of cooling on cells that serve to limit the maximum storage time, which can vary from just a few hours for hearts to more than 1 month for erythrocytes [24]. The storage of corneas as whole eyes in moist chambers is limited by the availability of metabolic substrates and build up of metabolic waste products in the aqueous humour; for example, a marked increase in lactate in aqueous was found during storage of whole eyes [25]. Following the application of cooling to whole eyes removed from deceased donors in the 1930s [9], the next major step towards improving corneal preservation was the storage of corneas excised from the eye with a rim of sclera (a corneoscleral disc). The storage of corneas in serum was first advocated in the 1960s, and this was soon followed by development of a synthetic solution whose ionic composition mimicked that of aqueous humour and which contained chondroitin sulphate and ascorbic acid [2527]. In the early 1970s, hypothermic storage of corneoscleral discs became the method of choice with the introduction of McCarey-Kaufman medium (M-K medium) [28]. This was simply tissue culture medium 199 (M-199) containing 5\% dextran 40. While the intention was to permit up to 7 days of storage at $4{ }^{\circ} \mathrm{C}$, a limit of 4 days was typical. Even with such a seemingly limited storage time, at least compared with blood, M-K medium had a major impact on the logistics of the supply of corneas for transplantation. While it has been superseded by solutions offering longer storage times, it is still in use today in developing countries because it is inexpensive and straightforward to produce.

Hypothermic storage times have been further extended with the development of solutions such as Optisol-GS [29], which is used extensively in US eye banks. This solution contains both dextran and chondroitin sulphate to control stromal hydration and a range of other supplements including vitamins and ATP precursors. Storage times up to 14 days are claimed but the epithelium is less well preserved than the endothelium, and many eye banks prefer not to exceed 7 days of storage. Metabolic support [30], countering damage from reactive oxygen species [31], nitric oxide synthase inhibitors [32], and use of non-ionic surfactants (Poloxamer 188) [33] have all been reported to be beneficial during hypothermic storage of corneas; but overall storage times have yet to be improved by these approaches.

Since Collins advocated so-called intracellular solutions to help control passive ionic fluxes and prevent cellular oedema, these have become the norm for organ preservation [34-35]. The term 'intracellular' in this instance merely refers to solutions with low sodium and high potassium ion concentrations; but they only approximate physiological intracellular concentrations. Solutions for corneal preservation have not pursued this course as it appears to have little beneficial impact. An intracellular-type solution containing the zwitterionic buffer TES did seemingly improve short-term hypothermic storage of rabbit corneas [36]. Similar results were obtained with a solution also containing TES but with high sodium and low potassium ion concentrations, which suggested that the reversal of ionic concentrations had little impact, at least for short-term storage.

\section{Organ Culture}

Of the 62 eye banks included in the 2010 European Eye Bank Association Directory, 47 used organ culture, 9 used hypothermia, and 6 used both methods: overall, $70 \%$ of corneas were stored by organ culture [15]. The most common organ culture medium is Eagle's minimum essential medium (MEM) with $2 \%$ fetal bovine serum (FBS), although up to $8 \%$ FBS is used by some eye banks. Most eye banks include penicillin, streptomycin and amphotericin B in their media: alternative antibiotics include biklin, tazocin, amukin and nystatin. Another difference in methodology is whether the medium is changed during organ culture storage: $40 \%$ of eye banks do not change the medium during storage while the remainder change the culture medium every 1-2 weeks. The concentration of dextran used to reverse stromal oedema that occurs during organ culture also varies from $4-8 \%$. Regardless of these differences, it would appear that graft outcomes are similar. Corneas are stored typically for up to 4 weeks [37], but successful transplants have been reported with corneas stored by organ culture for 7 weeks [38]. 
Organ culture has been the method of choice in the Bristol Eye Bank since it was established in the mid 1980s, and the following description is illustrative of the overall technique [39]. Before excision of corneoscleral discs, eyes are cleaned by rinsing in sterile saline and immersion in povidone-iodine to reduce bacterial and fungal contamination of the ocular surface. Corneas are suspended in $80 \mathrm{ml}$ Eagle's MEM containing HEPES buffer, $26 \mathrm{mmol} / 1 \mathrm{NaHCO}_{3}, 2 \%$ FBS, $2 \mathrm{mmol} / \mathrm{l} \mathrm{L-glutamine,} \mathrm{penicillin,} \mathrm{streptomycin} \mathrm{and} \mathrm{am-}$ photericin B, and stored at $34{ }^{\circ} \mathrm{C}$. Corneas contain viable cells and cannot be sterilized; however, compared with hypothermic storage, organ culture increases the chance of detecting bacteria and fungi that could potentially cause post-operative infection, and the antibiotics in the culture medium are far more effective the higher storage temperature. A sample of medium is taken after 7 days in organ culture to screen for bacteria and fungi, and further microbiological screening is carried out at the end of storage just before a cornea is issued for transplantation.

Corneas are stored for up to 4 weeks and their suitability for transplantation is based on examination of the corneal endothelium by light microscopy. This allows ECD to be estimated. In Bristol, a minimum ECD of 2,200 cells $/ \mathrm{mm}^{2}$ is considered acceptable for transplants requiring a viable endothelium. Other endothelial abnormalities or damage may also be identified and taken into account. Corneas stored in organ culture for up to 4 weeks have been shown to retain the integrity of both the endothelial and outer epithelial cell layers. Although corneal cells can be lost through apoptosis, this appears to affect epithelial more than endothelial cells [40]. The main factors that influence whether organ-cultured corneas meet the minimum endothelial criteria for full-thickness grafts are donor age and, to a lesser extent, storage time [39]. Although ECD typically declines with age, there are still many corneas from donors over 80 years that do meet the minimum criteria.

When organ culture was introduced in the UK in the mid 1980s, it had a major impact on the logistics of supply of corneas to hospitals throughout the country. There were two reasons for this: first, a national distribution service for corneas, similar to that already in place for organs, had been established just a few years previously; and, second, organ culture extended the storage time from just 2-4 days (whole eyes or corneas in M-K medium) to 4 weeks. Not only did this give far more time for the testing and medical assessment of donors, but it helped to manage fluctuations in donor supply and surgical demand. The application of organ culture in the UK meant that corneas were routinely made available for elective surgery and that there were always corneas available for clinically urgent transplants. These advantages are not necessarily peculiar to organ culture, but organ culture has certainly facilitated improvements in the quality, safety, and availability of corneas in the UK and other European countries.

\section{Recent and Future Developments}

Over the past few years, there has been a move towards the use of lamellar grafts (partial-thickness grafts) for replacing only those parts of the cornea that are failing [41-42]. Endothelial keratoplasty (EK) is being used increasingly to treat endothelial failure: instead of full-thickness grafts (penetrating keratoplasty; PK), a graft consisting of the endothelium on a thin layer of stroma or supported just on its basement membrane (Descemet's membrane) is used to replace a patient's failed endothelium. The advantages include far quicker visual rehabilitation (2-3 months instead of 1-2 years), and EK, unlike PK, induces virtually no astigmatism because no corneal sutures are required to fix the graft. For keratoconus and some stromal dystrophies, deep anterior lamellar keratoplasty (DALK) is an option that preserves a patient's own (healthy) endothelium while replacing virtually the whole thickness of the stroma. Thinner lamellar grafts may be used for anterior opacities and scars. None of these techniques have yet required modifications to the standard hypothermic or organ culture methods of storing corneas since the final graft is either prepared by the surgeon in the operating theatre or shortly before despatch from the eye bank.

The potential for modification of corneas during storage is being investigated. Since allograft rejection is a major cause of corneal graft failure, immunomodulation to reduce the immunogenicity of corneas is being attempted by transfection of endothelial cells to over-express down-regulatory cytokines, such as IL-10 and IL-12 [43]. Another approach is to encourage endothelial cells to divide during corneal storage by transfection with transcription factors such as E2F2, which has been reported to stimulate cell-cycle progression and endothelial replication [44]. There is also the prospect of a tissue-engineered corneal construct [45].

A different technique from corneal organ culture is used for ex vivo expansion of corneal epithelial stem cells. These cells are extracted from the limbal region between the cornea and the sclera, and they are used in the treatment of ocular surface disease where the corneal epithelium is defective. This is a painful and sight-threatening condition that is difficult to treat. The most successful application of this technique has been for unilateral ocular disease where sheets of stem cells can be established from a small limbal biopsy taken from the healthy fellow eye [46]. As with organ culture of corneas, the development of culture media free of bovine serum for limbal stem cell expansion is considered desirable [47-48]. These tissue constructs echo the trend in corneal transplant surgery for replacing only the defective parts of a cornea rather than relying on full-thickness grafts as the treatment of choice for all corneal deficiencies [49-50].

\section{Disclosure Statement}

The author declared no conflict of interest. 


\section{References}

1 Dikstein S, Maurice DM: The metabolic basis to the fluid pump in the cornea. J Physiol 1972;221: 29-41.

2 Meek KM, Quantock AJ: The use of x-ray scattering techniques to determine corneal ultrastructure. Prog Retin Eye Res 2001;20:95-137.

3 Joyce NC, Meklir B, Joyce SJ, Zieske JD: Cell cycle protein expression and proliferative status in human corneal cells. Invest Ophthalmol Vis Sci 1996;37:645-655.

4 Armitage WJ, Dick AD, Bourne WM: Predicting endothelial cell loss and long-term corneal graft survival. Invest Ophthalmol Vis Sci 2003;44:33263331

5 Vail A, Gore SM, Bradley BA, Easty DL, Rogers CA, Armitage WJ: Conclusions of the corneal transplant follow up study. Br J Ophthalmol 1997; 81:631-636.

6 Williams KA, Lowe MT, Bartlett CM, Kelly L, Coster DJ: The Australian Corneal Graft Registry 2007 Report. Adelaide, Flinders University Press, 2007.

7 Armitage WJ, Tullo AB, Larkin DFP: The first successful full-thickness corneal transplant: A commentary on Eduard Zirm's landmark paper of 1906. Br J Ophthalmol 2006;90:1222-1223.

8 Zirm E: Eine erfolgreiche totale Keratoplastik. Albrecht von Graefe's Archiv für Ophthalmologie 1906;64:580-593.

9 Filatov VP: Transplantation of the cornea. Arch Ophthalmol 1935;13:321-347.

10 Schroeter J, Rieck P, Maier P, Reinhard T: Augenhornhaut - Banken und klinische Anwendung. Transfus Med Hemother 2008;35:431-437.

11 Eastlund T: Infectious disease transmission through tissue transplantation: Reducing the risk through donor selection. Cell Transplant 1995;4:455-477 J.

12 Armitage WJ, Tullo AB, Ironside JW: Risk of Creutzfeldt-Jakob disease transmission by ocular surgery and tissue transplantation. Eye (Lond) 2009;23:1926-1930.

-13 Pruß A, Caspari G, Krüger DH, Blümel J, Nübling CM, Quenzel E-M, Kalus U, Gerlich W, Gürtler L: Nukleinsäure-Amplifikationstests für HIV, HBV und HCV bei Gewebespendern: Sinnvoll oder überflüssig? Transfus Med Hemother 2008;35:421430.

14 Cornea Donor Study Investigator Group; Gal RL, Dontchev M, Beck RW, Mannis MJ, Holland EJ, Kollman C, Dunn SP, Heck EL, Lass JH, Montoya MM, Schultze RL, Stulting RD, Sugar A, Sugar J, Tennant B, Verdier DD: The effect of donor age on corneal transplantation outcome. Ophthalmology 2008;115:620-626.

15 Claerhout I, Maas H, Pels E: European Eye Bank Association Directory Report, 18th ed. 2010. www. europeaneyebanks.org.

16 Thuret G, Manissolle C, Acquart S, Garraud O, Campos-Guyotat L, Maugery J, Gain P: Urgent need for normalization of corneal graft quality controls in French eye banks. Transplantation 2004;78: 1299-1302.

17 Ruggeri A, Grisan E, Schroeter J: Evaluation of repeatability for the automatic estimation of endothelial cell density in donor corneas. Br J Ophthalmol 2007;91:1213-1215.
Williams KA, Lowe M, Bartlett C, Kelly TL, Coster DJ: Risk factors for human corneal graft failure within the Australian corneal graft registry. Transplantation 2008;86:1720-1724.

19 Capella JA, Kaufman HE, Robbins JE: Preservation of viable corneal tissue. Cryobiology 1965; 2:116-121.

20 O'Neill P, Mueller FO, Trevor-Roper PD: On the preservation of corneae at -196 degrees $\mathrm{C}$ for fullthickness homografts in man and dog. Br J Ophthalmol 1967;51:13-30.

21 Schultz RO, Matsuda M, Yee RW, Glasser DB, Sabin SM, Edelhauser HF: Long-term survival of cryopreserved corneal endothelium. Ophthalmology 1985;92:1663-1667.

22 Armitage WJ, Hall SC, Routledge C: Recovery of endothelial function after vitrification of cornea at $-110{ }^{\circ} \mathrm{C}$. Invest Ophthalmol Vis Sci 2002;43:21602164.

23 Brunette I, Le Francois M, Tremblay MC, Guertin MC: Corneal transplant tolerance of cryopreservation. Cornea 2001;20:590-596.

24 Fuller BJ: The effects of cooling on mammalian cells; in Fuller BJ, Grout BWW (eds): Clinical Applications of Cryobiology. Boca Raton, CRC Press, 1991, pp 1-22.

25 Kuwahara Y, Sakanoue M, Hayashi M, Akiya S, Komoto M, Kumanomido A, Obazawa H, Nakano T, Hara T, Komukai M, Saga U, Tamura H, Ishihara K, Shimizu K, Takeda K, Ooshima T, Ozawa H: Studies on the long term preservation of the cornea for penetrating keratoplasty. Nippon Ganka Gakkai Zasshi 1965;69:1751-1840.

26 Stocker FW: Preservation of donor cornea in autologous serum prior to penetrating grafts. Am J Ophthalmol 1965;60:21-24.

27 Kuwahara Y, Sakanoue M: Preservation of donor eyes for penetrating keratoplasty (regarding medium term preservation). Nippon Ganka Kiyo 1968; 19:1319-1327.

28 McCarey BE, Meyer RF, Kaufman HE: Improved corneal storage for penetrating keratoplasties in humans. Ann Ophthalmol 1976;8:1488-1492.

29 Lindstrom RL, Kaufman HE, Skelnik DL, Laing RA, Lass JH, Musch DC, Trousdale MD, Reinhart WJ, Burris TE, Sugar A, Davis RM, Hirokawa K, Smith T, Gordon JF: Optisol corneal storage medium. Am J Ophthalmol 1992;114:345-356.

30 Chen CH, Rama P, Chen AH, Franch A, Sulewski M, Orlin S, Chen EH, Tseng SH, Lee H, Wang CC, Hung GY, Chan MY, Huang MS, Chen SC: Efficacy of media enriched with nonlactate-generating substrate for organ preservation: in vitro and clinical studies using the cornea model. Transplantation 1999;67:800-808.

31 Rauen U, Kerkweg U, Wusteman MC, de Groot H: Cold-induced injury to porcine corneal endothelial cells and its mediation by chelatable iron: implications for corneal preservation. Cornea 2006;25: 68-77.

32 Meisler DM, Koeck T, Connor JT, Aulak KS, Jeng BH, Hollyfield JG, Stuehr DJ, Shadrach KG: Inhibition of nitric oxide synthesis in corneas in storage media. Exp Eye Res 2004;78:891-894.

33 Steinhardt RA, Alderton JM: Poloxamer 188 enhances endothelial cell survival in bovine corneas in cold storage. Cornea 2006;25:839-844.
4 Collins GM, Halasz NA: Forty-eight hour ice storage of kidneys: importance of cation content. Surgery 1976;79:432-435.

35 Kalayoglu M, Sollinger HW, Stratta RJ, D'Alessandro AM, Hoffmann RM, Pirsch JD, Belzer FO: Extended preservation of the liver for clinical transplantation. Lancet 1988;1:617-619.

36 Taylor MJ, Hunt CJ: Hypothermic preservation of corneas in a hyperkalaemic solution (CPTes): I. Short-term storage in the absence of colloid osmotic agents. Br J Ophthalmol 1989;73:781-791.

37 Pels E, Schuchard Y: Organ-culture preservation of human corneas. Doc Ophthalmol 1983:56:147-153.

38 Ehlers H, Ehlers N, Hjortdal JO: Corneal transplantation with donor tissue kept in organ culture for 7 weeks. Acta Ophthalmol Scand 1999;77:277278.

39 Armitage WJ, Easty DL: Factors influencing the suitability of organ-cultured corneas for transplantation. Invest Ophthalmol Vis Sci 1997;38:16-24.

40 Crewe JM, Armitage WJ: Integrity of epithelium and endothelium in organ-cultured human corneas. Invest Ophthalmol Vis Sci 2001;42:1757-1761.

41 Van Dooren B, Mulder PGH, Nieuwendaal CP Beekhuis WH, Melles GRJ: Endothelial cell density after posterior lamellar keratoplasty (Melles techniques): 3 years follow-up. Am J Ophthalmol 2004;138:211-217.

42 van Dooren BTH, Mulder PGH, Nieuwendaal CP, Beekhuis WH, Melles GRJ: Endothelial cell density after deep anterior lamellar keratoplasty (Melles technique). Am J Ophthalmol 2004;137:397-400.

43 Williams KA, Brereton HM, Coster DJ: Prospects for genetic modulation of corneal graft survival. Eye (Lond) 2009;23:1904-1909.

44 McAlister JC, Joyce NC, Harris DL, Ali RR, Larkin DFP: Induction of replication in human corneal endothelial cells by E2F2 transcription factor cDNA transfer. Invest Ophthalmol Vis Sci 2005;46:3597-3603.

45 Griffith M, Osborne R, Munger R, Xiong X, Doillon CJ, Laycock NL, Hakim M, Song Y, Watsky MA: Functional human corneal equivalents constructed from cell lines. Science 1999;286:2169-2172.

46 Rama P, Bonini S, Lambiase A, Golisano O, Paterna $P$, De Luca M, Pellegrini G: Autologous fibrincultured limbal stem cells permanently restore the corneal surface of patients with total limbal stem cell deficiency. Transplantation 2001;72:1478-1485.

47 Thuret G, Manissolle C, Campos-Guyotat L, Guyotat D, Gain P: Animal compound-free medium and poloxamer for human corneal organ culture and deswelling. Invest Ophthalmol Vis Sci 2005; 46:816-822.

48 Kolli S, Ahmad S, Lako M, Figueiredo F: Successful clinical implementation of corneal epithelial stem cell therapy for treatment of unilateral limbal stem cell deficiency. Stem Cells 2010;28:597-610.

49 Fagerholm P, Lagali NS, Merrett K, Jackson WB, Munger R, Liu Y, Polarek JW, Soderqvist M, Griffith M: A biosynthetic alternative to human donor tissue for inducing corneal regeneration: 24-month follow-up of a phase 1 clinical study. Sci Transl Med 2010;2:46-61.

50 Griffith M, Jackson WB, Lagali N, Merrett K, Li F, Fagerholm P: Artificial corneas: a regenerative medicine approach. Eye (Lond) 2009;23:1985-1989. 